\title{
HEALTH IN INDUSTRY
}

IN a foreword to a publication issued by the Ministry of Labour, the Minister, Mr. John Hare, directs attention to the fact that more than 300 million working days are lost each year in Great Britain because of sickness or injury.

The Minister's foreword is contained in the booklet, Health at Work*, which gives fourteen examples of individual industrial health schemes operating successfully in factories in different parts of Great Britain. and the Minister hopes that these examples will encourage other firms to follow suit. The booklet is being widely distributed to factory occupiers by H.M. Factory Inspectorate. It deals with such questions as how factory medical services are organized, and what they achieve, the attitudes of workers to their introduction and the advantages derived by both employer and worker.

In carrying out the survey, the Ministry obtained from each factory details of the nature of the work done there, the organization of the medical services, the work of the medical officers and nursing staff, and the cost of each scheme. Four of the factories employ from 231 to 300 workers ; five employ from 500 to 1,000 ; three from 1,000 to 5,000 , and two more than 5,000. Included in the industries represented are heavy engineering and foundry work, copper and metal refining, the manufacturing of electric cookers, refrigerators, electro-plated ware, carbon black, printing machinery, animal feeding stuffs and vegetable oil. Also included are wool and worsted spinning, the processing of asbestos yarns and pipes, and the preparation of insecticides, fungicides, fine chemicals and pharmaceuticals.

Fear about costs is suggested as being the biggest single factor in preventing a more rapid spread of industrial health schemes. The booklet gives detailed figures of the cost of the schemes provided. The annual running costs vary widely according to the

* Ministry of Labour. Health at Work : a Description of Medical Services in Fourteen British Factories. Pp. 76. (London: Ministry of Labour, 1960.) nature of the services provided and the numbers employed. Of the 14 schemes described, seven cost $£ 2$ or less a head per annum, five cost betwe $\theta$ n $£ 2$ and $£ 3$, and the other two more than $£ 3$. The booklet also mentions an attempt at another factory to weigh in terms of cash the worth or value of such a scheme. This led to the conclusion that, on a conservative estimate, the annual recurring costs of the medical scheme were more than covered by savings in time lost, and that the long-term benefits in better health and morale were a bonus alike to the company and the employee.

It is emphasized that the booklet does not intend to provide a ready-made pattern from which an employer can pick a scheme to suit his pocket, or the size of his factory and his business. What it does show is how, in practice, such schemes are operating to meet particular needs of particular firms, and the considerable variety of functions which the services can perform to the advantage of employers and workpeople. The reasons why firms considered it worth while to spend more money voluntarily on medical supervision varied according to the type of industry, but the following were typical: (1) the pre-employment examination was a safeguard to management and workers ; (2) from a practical point of view, speedy attention to accidents and illhealth saved time; (3) improvement in relations between employers and workers resulted from such a scheme.

The general impression drawn from reactions on the part of workers was that schemes of medical supervision deseribed in the booklet provided a personal service which the workers greatly appreciated. The fact that immediate and expert attention could be given to the injured and sick aroused a feeling of confidence among them. The booklet indicates that in one or two instances there was some initial suspicion on the part of workers which soon disappeared with experience of the working of the schemes.

\section{ELM DISEASE}

\begin{abstract}
ATHOUGH the elms are not, nowadays, regarded as important species in forestry proper, the Forestry Commissioners sometimes feel that it is incumbent on them to devote time and money to conduct research into problems concerned, with trees in which the British public as a whole are generally interested. A recent publication*, which would have been more correctly described as referring to southern England, deals with such a case. It is concerned with a fungous disease of elms caused by Ceratostomella ulmi (Schwartz) Buis., which was first recorded in France in 1918, and in Holland in 1919, and is suspected as having been introduced with elms imported from eastern Asia. It soon became widespread in northern Europe and in North America.
\end{abstract}

* Forestry Commission, Bulletin No. 33 : The Status and Develop ment of Fim Disease in Britain plates. (London: F.M. Stationery Office, 1960.) 10s, net.
It was first recorded in England in 1927, by which time it was giving much concern to tree-growers in Holland, where its severity at one time earned for it the title of the Dutch elm disease. The effect of the fungus is to cause a vascular wilting of the leaves followed by the death of twigs and branches and even of whole trees. The unsightliness of the dead trees must have attracted the attention of all who travel through those counties where elms are such a notable feature of the landscape. The disease was probably present in Great Britain before its first recording.

The task of studying this disease and of keeping an oyo on it was entrusted by the Forestry Commission in 1928 to $\mathrm{Mr}$. T. R. Peace while he was stationed at the Imperial Forestry Institute, Oxford, and he has continued to do this since his appointment to the staff of the Commission, where he is now chief research officer. The present publication, issued by 
the Forestry Commission, is based on his work, and especially on surveys undertaken by him, during the 31 years up to 1959 , but he also acknowledges his debt to American workers in Great Britain in the same field.

This disease is one in which there is a very intimate connexion between two organisms, one from the plant world, the other from the animal world. In 1931 this was established by Fransen, who found that bark beetles of the genus Scolytus were carriers of the fungus, which can also enter the tree through wounds and especially through the roots, which, from the suckering habit of the English elm, must be not uncommon.

The surveys revealed that the disease reached its poak in 1931, and that it has steadily declined since 1936-37, not only in the number of elms attacked but also more especially in the severity of the damage caused. It is suggested that the war-time clearance of diseased elms, made possible by the opportunity to market the timber, may nave led to a reduction in the beetle population and to infections due to it. It is estimated that the total loss due to the disease lies between 10 and 20 per cent of tree elms, and that this is being made good by sucker growth. Two lines of action were taken to combat the disease.
In Holland and the United States a policy of widespread felling of diseased trees was adopted; in Great Britain things were left to run their course. In view of the considerable degree of recovery of diseased trees, in support of which the author provides many good plates, he is perhaps justified in concluding that the loss of elms would have been much greater in Britain if the first policy had been adopted. He advises the awaiting of the field trials of strains resistant to the fungus before widespread planting of elms in hedgerows or for amenity is undertaken. The disease may long continue as a minor nuisance, but is not expected to bring about the disaster of complete annihilation of the elms immemorial. The great weakness of the investigation undertaken by Mr. Peace is one that is associated with most of the publications of the Forestry Commission, namely, lack of appreciation of the importance of allowing for locality differences. The data in respect of both climate and soil are quite inadequate for the treatment of such an exacting genus as Ulmus. When a study is allowed to range over a wide variety of site conditions, it is essential that it should be handled in such a way that site variation is allowed for.

M. L. ANDERSON

\title{
PHOTO-EMISSION FROM METAL SURFACES MEASURED WITH GEIGER COUNTERS
}

\author{
By M. A. CONRAD and S. LEVY
}

\author{
Applied Research Laboratory, United States Steel Corporation, Monroeville, Pennsylvania
}

\begin{abstract}
$\mathrm{D}^{1}$ URING the past several years, J. Kramer has investigated a group of phenomena involving the emission of low-energy electrons from solid surfaces. The findings are summarized in two of his papers ${ }^{1}$. This work by Kramer, more recently extended by others, provides an interesting and sensitive new method for investigating the surface condition of both metals and non-metals. Through studies of this so-called Kramer effect, some insight has been gained into a number of phenomena, such as the delayed emission of electrons ('exo-electrons') that occurs when certain non-metals (for example, aluminium oxide powder and gypsum) are crushed or irradiated; the dependence of photo-emission on surface treatment of metals; and electron emission caused by heating below the temperature of thermionic emission. For purposes of theoretical interpretation, and determination of possible practical applications, it is essential to know whether these phenomena are inter-related, and to what extent. The purpose of this article is to report some preliminary experimental observations obtained during an investigation of these phenomena in our Laboratory that we believe are pertinent to this problem.

The emission of low-energy electrons from bulk specimens of several metals of commercial purity (aluminium, tin, copper, nickel and zinc), before and after various mechanical treatments (abrasion, filing, polishing and compression), was measured by means of windowless Geiger-flow counters at room temperature. The specimen, in the form of a disk, $\frac{1}{4}$ in. thick and $1 \mathrm{in}$. in diameter, formed a part of
\end{abstract}

the cathode; in one of the counters with a fused quartz envelope, the specimen constituted the largest part of the cathode. The distance of the anode 'point' of the counting tube from the specimen was $\frac{3}{4}$ in. The tubes were operated in the voltagerange of $1,200-1,300$, where the extent of the plateau was at least $150 \mathrm{~V}$. The flowing gas, at atmospheric pressure, consisted essentially of helium (about 98.5 per cent) and contained isobutane as the quenching agent; a small amount (about 0.05 per cent) of water vapour was detected in this gas by mass spectrometry. The background radiation during these measurements was determined to be about 25 counts per minute.

Contrary to the findings of some investigators ${ }^{2}$, we detected no emission of electrons from the freshly abraded, filed, or compressively strained metal specimens when the Geiger counters were made completely light tight. In other testa we have made with a quartz-envelope Geiger counter, emission was detected only when the light shielding was not adequate. Evidently, the intensity of stray light needed to induce photo-electron emission from mechanically treated metal surfaces is extremely low. Thus it appears that true delayed emission of low-energy electrons (exo-electrons) does not occur in the absence of any stray light during the detection phase of the experiment.

The blackening of photographic emulsions in contact with freshly deformed or abraded metal surfaces (the so-called Russell effect) is known to result from the formation of hydrogen peroxide at 